\title{
THE RELATION OF DIAPHORASE OF HUMAN ERYTHROCYTES TO INHERITANCE OF METHEMOGLOBINEMIA
}

\author{
By E. M. SCOTT \\ (From the Arctic Health Research Center, United States Public Health Scricice, \\ Anchorage, Alaska)
}

(Submitted for publication February 23, 1960; accepted March 17, 1960)

Hereditary methemoglobinemia has been found to have a relatively high prevalence in Alaskan Eskimos and Indians (1). Persons with this condition have been found to have a complete lack of diphosphopyridine nucleotide diaphorase activity in red cells (2).

Of the 21 known cases of methemoglobinemia in 13 families in Alaska, 12 cases in 7 families occurred in Ingalik Indians, a small group of about 800 Athabascans living on the Innoko, Yukon and Kuskokwim Rivers. The present study is concerned with a study of diaphorase levels of red cells of 271 of these people and of 47 Eskimos living nearby. Evidence is presented which indicates that parents of methemoglobinemic children have about half the normal level of erythrocyte diaphorase, and that the condition is inherited as a simple recessive trait.

\section{METHODS}

Determination of crythrocyte diaphorase. Five $\mathrm{ml}$ of blood was collected and mixed with $1 \mathrm{ml}$ acid citrate dextrose (ACD) solution ( $1.47 \mathrm{~g}$ glucose, $1.32 \mathrm{~g}$ sodium citrate and $0.44 \mathrm{~g}$ citric acid per $100 \mathrm{ml}$ water). Other anticoagulants can be used but we have preferred ACD since the diaphorase level could not be determined until several days after the blood was collected. In the presence of ACD, the diaphorase level of cells was unchanged over a period of at least 2 weeks. The serum was drawn off and the cells were washed 3 times with 10 volumes of phosphate-buffered saline solution ( 9 volumes 0.9 per cent $\mathrm{NaCl}$ plus 1 volume $0.1 \mathrm{M}$ potassium phosphate, $\mathrm{pH}$ 7.3). To the cells was added an equal volume of phosphate-buffered saline solution containing 1 per cent sodium nitrite and the mixture was shaken and allowed to stand for 20 minutes. The cells were then washed 5 more times with 10 volumes of phosphatebuffered saline solution to completely remove the nitrite.

To $0.1 \mathrm{ml}$ of the oxidized cells was added $1.9 \mathrm{ml}$ water. After shaking, the mixture was centrifuged and the hemolysate decanted from the insoluble matter. The methemoglobin content of the hemolysate was determined by measuring absorption at $600 \mathrm{~m} \mu$ after $1: 15$ dilution; it was found by comparison with the method of Evelyn and
Malloy (3) that an optical density of 0.2 at $600 \mathrm{~m} \mu$ in a $10 \mathrm{~mm}$ cell was given by $1.08 \mathrm{mg}$ methemoglobin per $\mathrm{ml}$.

To each of two cuvets were added $0.05 \mathrm{ml} 1 \mathrm{M}$ Tris (hydroxymethyl)aminomethane $(\mathrm{pH} 7.55), 0.1 \mathrm{ml} 0.01$ $\mathrm{M}$ sodium ethylenediamine tetraacetate (EDTA) and 0.05 $\mathrm{ml} 0.0012 \mathrm{M}$ 2,6-dichlorobenzenoneindophenol (Eastman). To one cuvet was added hemolysate equivalent to $3.25 \mathrm{mg}$ methemoglobin and water to a volume of 2.98 $\mathrm{ml}$; to the blank was added $2.78 \mathrm{ml}$ water. The reaction was started by addition of $0.02 \mathrm{ml} 0.0088 \mathrm{M}$ reduced diphosphopyridine nucleotide (DPNH). Optical density in a $10 \mathrm{~mm}$ cell was measured at 3-minute intervals for 21 minutes at $600 \mathrm{~m} \mu$ in a Beckman spectrophotometer. The spectrophotometer was equipped with a water jacket, through which water at $25^{\circ} \mathrm{C}$ was circulated.

Under these conditions, the decrease in optical density both with hemolysate and in the blank was nearly linear. The level of diaphorase activity of the hemolysate was taken to be the rate of reaction expressed as change in absorbance per minute ( $\triangle \mathrm{A}$ per minute) corrected for the blank.

\section{RESULTS}

A typical plot of results obtained with this method is shown in Figure 1. It will be noted that the rate of reduction with dye in the presence of methemoglobinemic hemolysate is not distinguishable from the blank rate. The net rate of reduction of 2,6-dichlorobenzenoneindophenol has been determined in 14 methemoglobinemic persons representing 11 families, and 13 parents of methemoglobinemic children representing 8 families. The results are summarized in Table $I$, and compared with those from 88 children of normal parents. The level of diaphorase in red cells of men did not differ from that of women, and there was no dependence on age.

Determinations of diaphorase activity have been made on 271 Ingalik Indians and 47 Eskimos with the results shown in Figure 2. It is apparent from this figure that the levels fall into three groups. The first consists of clearly distinguishable levels between -0.0001 and $0.0005 \Delta \mathrm{A}$ per minute and represents only methemoglobinemic persons. 
The second group begins at levels of $0.0015 \Delta \mathrm{A}$ per minute and extends to about $0.0030 \Delta \mathrm{A}$ per minute; all parents of methemoglobinemic children were in this group. The third and largest group consisted of levels higher than about $0.0030 \Delta \mathrm{A}$ per minute.

Assuming that levels lower than 0.0010 are characteristic of the methemoglobinemic homozygote, $\mathrm{mm}$; levels between 0.0010 and 0.0030 represent the heterozygote, $M m$; and levels in excess of 0.0030 the normal homozygote, $M M$ : the results in 45 families can be summarized as shown in Table II. A considerable proportion of the

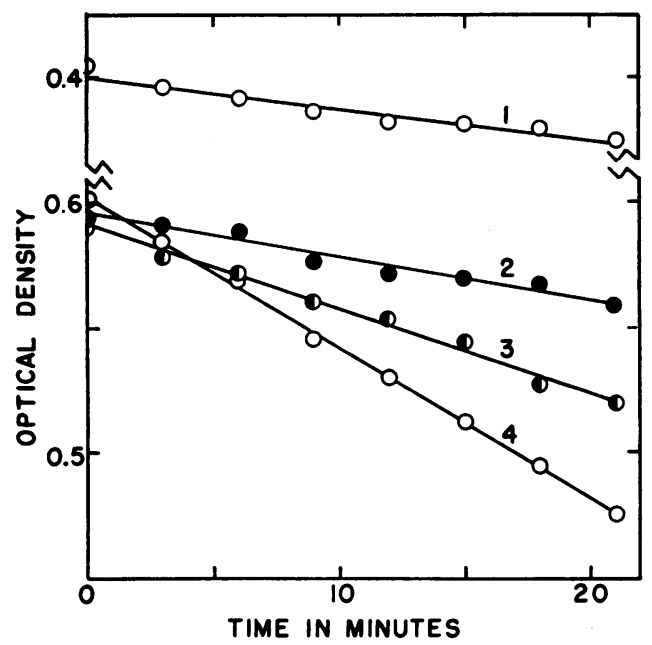

Fig. 1. Rate of dye Reduction. 1) Reaction in absence of hemolysate; 2 ) reaction with hemolysate from methemoglobinemic subject; 3 ) reaction with hemolysate from a heterozygotic sibling of 2 ; 4) reaction with hemolysate from a normal sibling of 2 .

persons with low levels is related; the relationship is shown in Figure 3.

\section{DISCUSSION}

The method here used for determining diaphorase activity is adapted from that of Edelhoch, Hayaishi and Teply (4). In applying this method to hemolysates, it was necessary to oxidize all hemoglobin to methemoglobin, since hemoglobin itself will rapidly reduce 2,6-dichlorobenzenoneindophenol. The dye is also reduced directly by DPNH. This nonenzymatic reaction is first order with respect to dye concentration and also with respect to DPNH concentration. It is strongly
TABLE I

Net rate of dye reduction in methemoglobinemic persons; parents of methemoglobinemic children, and children of normal parents

\begin{tabular}{lcccc}
\hline & & \multicolumn{3}{c}{ Rate of dye reduction* } \\
\cline { 3 - 5 } Subjects & No. & Mean & SD & Range \\
\hline Methemoglobinemic & 14 & 0.9 & 2.1 & -3 to 5 \\
$\begin{array}{c}\text { Parents of methemo- } \\
\text { globinemic children }\end{array}$ & 13 & 21.8 & 4.4 & 15 to 28 \\
$\begin{array}{c}\text { Children of normal } \\
\text { parents }\end{array}$ & 88 & 45.5 & 8.5 & 28 to 81
\end{tabular}

* Rate of dye reduction is expressed as absorbance change per minute $\times 10^{4}$.

dependent on $\mathrm{pH}$, being very rapid at lower $\mathrm{pH}$. At the $\mathrm{pH}$ used (7.55), the reaction is sufficiently slow so that a nearly linear reduction occurs. We have been unable to obtain a reproducible rate of nonenzymatic reduction of the dye in the absence of EDTA although this substance has no effect on the enzymatic reaction. The net rate of reaction is proportional to the amount of hemolysate added, but the amount of hemolysate that can be used is limited by the optical density of the solution.

That the factor contributed by the hemolysate is an enzyme is shown by its lability to heat and the fact that it can be purified by conventional methods of enzyme isolation. The properties of the purified enzyme will be described elsewhere. The enzyme of hemolysates is relatively stable; about one-third of the activity was lost after freezing and no further loss occurred after storage in the frozen state for six months.

The activity of the diaphorase in hemolysates is

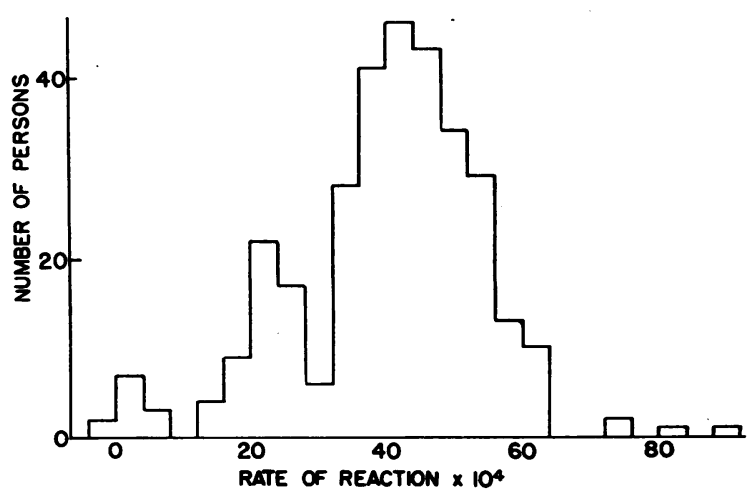

Fig. 2. Net rate of dye Reduction in 318 subjects. Rate of reaction is expressed as absorbance change per minute. 
TABLE II

Diaphorase levels of children compared with those of parents

\begin{tabular}{|c|c|c|c|c|}
\hline \multirow[b]{2}{*}{ Parents } & \multirow[b]{2}{*}{$\begin{array}{c}\text { No. of } \\
\text { families }\end{array}$} & \multicolumn{3}{|c|}{ No. of children with levels: } \\
\hline & & $<0.0010^{*}$ & $\begin{array}{l}0.0010- \\
0.0030^{*}\end{array}$ & $>0.0030^{*}$ \\
\hline $\begin{array}{c}M M \times m m \\
M m \times M m \\
M m \times M M \\
M M \times M M\end{array}$ & $\begin{array}{r}1 \\
5 \\
10 \\
29\end{array}$ & $\begin{array}{l}0 \\
7 \\
0 \\
0\end{array}$ & $\begin{array}{l}4 \\
7 \\
7 \\
1\end{array}$ & $\begin{array}{r}0 \\
5 \\
15 \\
87\end{array}$ \\
\hline
\end{tabular}

* Net rate of diaphorase reaction.

strongly dependent on $\mathrm{pH}$. It is more active at lower $\mathrm{pH}$ but the reaction cannot be conveniently determined at lower $\mathrm{pH}$ because the nonenzymatic reaction is also accelerated. The rate of enzymatic reaction is nearly directly proportional to initial dye concentration. Although one would anticipate that dye reduction would therefore be a first order reaction, it is nearly linear under the above conditions. The reason for this discrepancy is not known. The enzymatic reaction, unlike the nonenzymatic reaction, is nearly independent of DPNH concentration. That no diaphorase activity is present in methemoglobinemic hemolysates is shown by the fact that rate of dye reduction in the presence of these hemolysates is proportional to DPNH concentration.

It will be noted in Figure 2 that a few persons with diaphorase levels between 0.0028 and 0.0032 $\Delta \mathrm{A}$ per minute can not unequivocally be placed in either the normal group or in the group which appears to be heterozygous. A decision on such an individual can often be reached by repeating the diaphorase assay, since the variation encountered between assays may be as high as $0.0004 \Delta \mathrm{A}$ per minute. (The data in Figure 2 were the results of a single determination of diaphorase activity.) Studies of the immediate family may also be helpful in reaching a decision in a doubtful case.

In spite of the fact that low levels of diaphorase may not always be readily distinguishable from normal levels, the evidence obtained from these families is clearly consistent with the view that persons who are heterozygous for methemoglobinemia have diaphorase levels about half as high as normal levels. We have not been able to detect methemoglobin in the red cells of any of these heterozygotes.

Of the 318 persons tested in this study 203 were selected by a random process-they included all families in the area in which both parents were living and there were children six or more years of age. (The other 115 were close relatives of methemoglobinemic subjects.) Of these 203, 3 were methemoglobinemic and 22 were apparently heterozygous. The gene frequency in this group was thus 0.069 . It would be anticipated from this frequency that normal persons, heterozygotes and methemoglobinemics would be found in the ratio $176: 26: 1$; this is probably not significantly different from the 178:22:3 found. The distribution of diaphorase levels shown in Table II, the data in Figure 3, and data from other families in the study are also consistent with the inheritance of methemoglobinemia as a simple recessive trait.

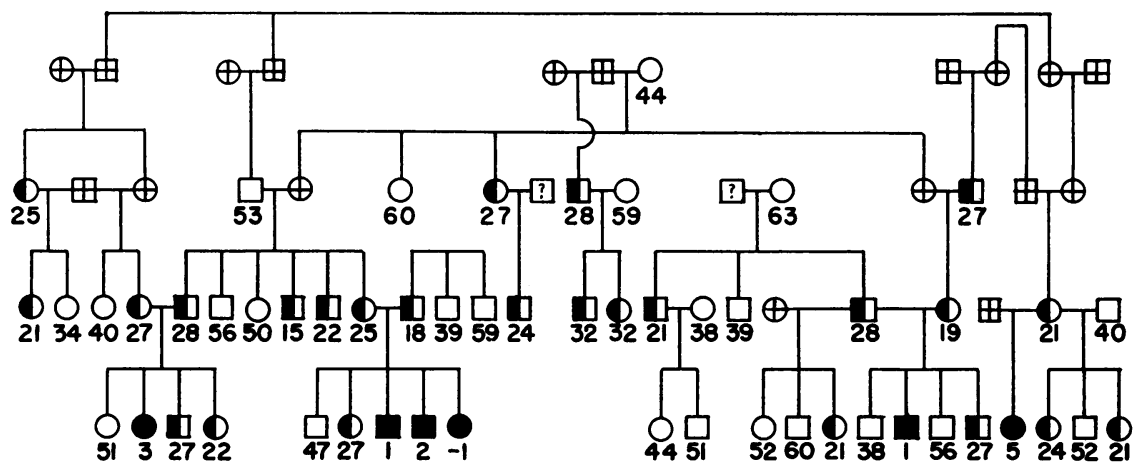

Fig. 3. Relationship of methemoglobinemic families. The figures are net rate of dye reduction in absorbance change per minute $\times 10^{4}$. Circles $=$ females, squares $=$ males, solid symbols $=$ methemoglobinemic subjects, half-solid symbols $=$ heterozygotes, open symbols = normal, crossed symbols = deceased : question mark indicates diaphorase not determined or person unknown. 
SUMM ARY

Diphosphopyridine nucleotide diaphorase activity is lacking in the red cells of persons with hereditary methemoglobinemia, and is present in only about half the normal amount in parents of methemoglobinemic children. Low levels of erythrocyte diaphorase appear to be characteristic of the heterozygous state of methemoglobinemia. The evidence obtained supports the conclusion that methemoglobinemia is inherited as a recessive trait.

\section{REFERENCES}

1. Scott, E. M., and Hoskins, D. D. Hereditary methemoglobinemia in Alaskan Eskimos and Indians. Blood 1958, 13, 795.

2. Scott, E. M., and Griffith, I. V. The enzymic defect of hereditary methemoglobinemia: Diaphorase. Biochim. biophys. Acta 1959, 34, 584.

3. Evelyn, K. A., and Malloy, H. T. Microdetermination of oxyhemoglobin, methemoglobin and sulfhemoglobin in a single sample of blood. J. biol. Chem. 1938, 126, 655.

4. Edelhoch, H., Hayaishi, O., and Teply, L. J. The preparation and properties of a soluble diphosphopyridine nucleotide cytochrome $c$ reductase. J. biol. Chem. 1952, 197, 97. 